http://dx.doi.org/10.30681/23588403v12i03184195

\title{
BEYOND MECHANICAL SKILLS IN THE ENGLISH LANGUAGE CLASSROOM: WORKING WITH FAKE NEWS FROM THE DIGITAL LITERACIES PERSPECTIVE
}

\author{
Nayara Stefanie Mandarino SILVA (UFS) ${ }^{1}$
}

Data de recebimento: 07/10//2019

Aceite: 16/11/2019

\begin{abstract}
Resumo: Os avanços tecnológicos e o acesso à internet contribuem com a disseminação de fake news, um fenômeno que não é novo, mas que agora acontece no ciberespaço. Como consequência, debates sobre como as pessoas deveriam lidar com informações na era da pósverdade têm ocorrido. A língua é crucial tanto na produção quanto na interpretação de fake news; o inglês se destaca nesse processo devido ao seu grande número de usuários. Uma das possiblidades de lidar com esse fenômeno na aula de Inglês é a teoria dos letramentos digitais que é discutida neste artigo cujo objetivo é analisar uma experiência com fake news na aula de Inglês, com ênfase nas possibilidades de desenvolvimento de habilidades relacionadas à supracitada teoria para lidar com esse tipo de notícia. A metodologia utilizada é qualitativa de cunho analítico interpretativo, com análise baseada na proposta de Freeman (1998): nomear, agrupar, encontrar relações e exibição dos dados. Por fim, concluo que o trabalho com letramentos digitais na sala de aula de Inglês pode ajudar os alunos a lidar com fake news, considerando que é necessário ir além de habilidades mecânicas do uso de dispositivos digitais e refletir sobre os comos e os porquês de interpretarmos textos da forma que fazemos.
\end{abstract}

Palavras-chave: fake news. Letramentos Digitais. Língua inglesa. Educação.

\begin{abstract}
The advances in technology and the access to internet contribute to the spread of fake news, a phenomenon that is not new, but that is happening in a new environment - the cyberspace. Considering this reality, there have been debates related to how people (should) deal with information in the so-called post-truth era. Language is crucial in both the production and interpretation of fake news; English stands out in this process due to its number of users all over the world. One of the possibilities to deal with this phenomenon in the English language class is the digital literacies theory discussed in this paper which aims at analyzing an experience with fake news in the English classroom, focusing on possibilities in the development of digital literacies skills to deal with this kind of news. Regarding the methodology, this paper is a qualitative - analytical-interpretative - research. The analysis was based on Freeman's (1998) four steps: naming, grouping, finding relationship, and displaying. Finally, I conclude that working with the digital literacies theory in the English classroom can help students deal with fake news, considering that it requires not only mechanical skills, but also reflection on how and why we interpret texts the way we do.
\end{abstract}

Keywords: fake news. Digital Literacies. English language. Education.

\footnotetext{
1 Aluna da graduação em Letras Português-Inglês, na Universidade Federal de Sergipe (UFS). É também professora de inglês do Idiomas sem Fronteiras e pesquisadora, desde 2017, em projetos de iniciação científica. nayaramandarino@hotmail.com
} 


\section{First words}

Globalization has brought changes in society. They affect, among other things, the ways in which we construct meanings, and, consequently, how we learn and communicate. We are emerged in the so-called digital technologies age. When we look around, we can see how devices like computers and, especially, smartphones are part of our routines. The advances in technology allow what Santaella (2013) calls ubiquity, defined as the possibility to access information and to communicate with others anytime and anywhere. Accessing news was never so easy as it is nowadays, however the point is how we deal with so much information. Kalantzis and Cope (2006) argue that in modern models, people had been taught to receive the truth. They exemplify their argument by saying that the ideal of school practices involves teachers telling facts and truths to students who should sit and absorb them. Such model may have contributed to the belief in the veracity of fake news, a constant phenomenon on cyberspaces.

The changes on how we get information require modifications on how we deal with it. The digital literacies theory discusses the skills necessary to engage with digital technology critically. Based on this theory, this paper aims to analyze an experience with fake news in the English classroom, focusing on possibilities in the development of digital literacies skills to deal with this kind of news. In order to so, we discuss the mentioned theory, the definition of fake news, and we analyze an experience that took place on the Institutional Scholarships Program of Teaching Initiation (PIBID), from the end of 2017 to the beginning of 2018. This program is linked to the Federal University of Sergipe (UFS) and to the Coordination for the Improvement of Higher Education Personnel (CAPES). ${ }^{2}$

This paper is a qualitative - analytical-interpretative - and bibliographic research. The methodological procedure is based on Freeman (1998). First, I discuss the concept of digital literacies. In the second topic, I address the definitions of post-truth and fake news. I focus the above-mentioned experience in the third topic, where I also analyze data following Freeman's (1998) framework in four steps: naming, grouping, finding relationship, and displaying.

\section{What do digital literacies mean?}

Lankshear and Knobel (2006-2016) discuss the concept of digital literacy stemming from two different kinds. The first one is conceptual definitions. It understands literacy as a set

${ }^{2}$ I thank CAPES for the support offered to PIBID-UFS. 


\section{Revista de Estudos Acadêmicos de Letras}

of abilities that enables people to analyze information, including multimodal texts, and to adapt texts to different contexts and audiences. That being said, digital literacy is defined as a group of skills that goes beyond the mechanical use of digital technologies. They enable people to understand, evaluate and attribute new meanings to information they find online. Based on Gilster (1997), the authors mention four essential competencies related to digital literacy: "knowledge assembly, evaluating information content, searching the Internet, and navigating hypertext.” (LANKSHEAR, KNOBEL, 2006-2016, p. 9).

The second kind, in the authors' words, is defined as "standardized sets of operations intended to provide national and international normalizations of digital literacy." (LANKSHEAR, KNOBEL, 2006-2016, p. 8). In this sense, there is an attempt to define a standard of what skills a digitally literate person should have.

The authors, then, point out three features that regard digital literacy mainstream definitions: they understand the theory as dealing with information; they see the theory as a means to check the veracity of information and to escape from being manipulated; finally, digital literacy is seen as something you can have, and that is necessary to deal with information. According to Lankshear and Knobel (2006-2016), these points are to be problematized, because thinking of digital literacy as dealing with information leads to a misunderstanding on what concerns human interaction. In addition, the "veracity" of a piece of information is permeated by power relations. Therefore, certain groups with more authority would define what is the truth. They argue that digital literacy is not a "thing" you can have and use neutrally in any context, it is totally related to social practices, functions, contexts, and discourses. Acknowledging that there are different sociocultural realities, the authors defend that we should think of digital literacy in a plural form, digital literacies.

We should think of «digital literacy» as shorthand for the myriad social practices and conceptions of engaging in meaning making mediated by texts that are produced, received, distributed, exchanged etc., via digital codification. Digital literacy is really digital literacies. [...] There are many different social practices and conceptions of searching, of navigating links, of evaluating credibility of sources, of «posting,» and so on. These vary according to how people «identify» themselves. (LANKSHEAR, KNOBEL, 2006-2016, p. 13, authors' emphasis).

In this sense, our practices in digital environments - the so-called cyberspace that involves the communication space made possible by computers (Santaella, 2013) - are intrinsically related to our culture, rather than only to a set of technical skills. Xavier (2015) 


\section{Revista de Estudos Acadêmicos de Letras}

mentions yet another aspect of digital literacies. He defends that users have to develop new reading and writing practices. Santaella (2013) addresses some of these changes; for instance, multitasking users and what she calls "ubiquitous reader" who is able to transit among digital spaces and reacts to multiple stimuli. Users' cognition, therefore, is affected.

Nascimento (2014) reinforces that there are possibilities of constructing knowledge in cyberspaces, and explains that the constructions are social, but not democratic. Therefore, human's active and critical role towards technology is essential. In the educational environment, such arguments imply that teachers should help students in the process of reflecting on how they use digital technology. However, in order to so, teachers themselves must reflect on how they use such devices, because using these tools to repeat the same old educational practices does not mean that teachers are working from a digital literacies perspective and stimulating the critical use digital technology. Teachers were seen as a source of information. However, now information is available for everyone with access to the internet. Students need to learn how to construct knowledge from a set of contents, and teachers have the mission to help them in this continuous process (BRAGA, 2013).

\section{Fake news in the post-truth era}

In order to define the concept of post-digital reality, Santaella (2016) presents the origin of the prefix "post" which started being used in 1980 associated with the modernity (postmodernity). It was also put before the word human (post-human) to refer to how technologies were changing the human body. The author explains that cellphones have been changing our notions of what is the virtual versus the real world, because now they coexist complexity, that is digital devices permeate our everyday lives, so we are constantly connected with both worlds. In this context, the term post-virtual emerged. Considering that now "the computational universe presence permeates all segments of our life" (SANTAELLA, 2016, p. 83), the term post-digital is used referring to a moment when changes occasioned by digital technologies become common, that is, when they are no longer seen with big surprise. It is opposed, therefore, to the term new media, considering that now "new" and "old" media interact in ways that it is not possible to say where ends and the other starts. In addition to the terms that use the prefix "post", there is post-truth. It highlights that the truth no longer matters, it has become secondary, because now it is not about hiding the truth to deceive people, but to reinforce their personal beliefs (SANTAELLA, 2018). Human emotions are exerting power over rationality; 


\section{Revista de Estudos Acadêmicos de Letras}

content that causes more indignation is more spreadable in environments where debates take place, so someone can win the argument, according to Santaella (2018). This leads to the reinforcement of opinions, which seem to be the only truth, but, in fact, the search for the truth is impossible, since it is a socially constructed reading.

Santaella (2018) states that another phenomenon in the cyberspace contributes to fake news: filter bubbles. Algorithms that track everything we access on the internet personalize online experiences. In this sense, we are shown sites, ads, pages that reflect our beliefs; consequently, our viewpoints are reinforced whilst we are not exposed to other ideas. Humans, which seeks for confirmation, contributes to the spread of fakes news, because

there is no rational argument capable of supplanting it [belief]. This is what cognitive psychologists call 'confirmation bias', that is, 'when someone in confronted with information that goes against their world view, the chances that they will accept the new data as a fact, change their mind, or question the belief system itself are quite low'. This is due to that accepting information which confirms our beliefs speaks louder than 'rejecting the ones that contradict them'." (SANTAELLA, 2018, p. 13). ${ }^{3}$

In addition to that, users who don't check the veracity of information tend to believe that the news they get is impartial. Our minds are attracted to familiar patterns, this is the reason why we believe more easily in news that reflects our viewpoint.

Pennycook et al (2018, p. 1865) define fake news as "news stories that were fabricated (but presented as if from legitimate sources) and promoted on social media to deceive the public for ideological and/or financial gain.” In this sense of fake information, Santaella (2018) highlights that this is not a new concept, what is new is how people produce, share, and interpret news, due to the digital culture in which people produce and get content that is not put through journalistic editions, for instance. Fake news now appeals to users' emotional reaction. The author explains that there are different levels of falsehood within fake news. Based on Claire Wandle, Santaella (2018, p. 30) points out seven of its types:

(a) satire or parody that, even though has no intention of causing harm, has the potential to deceive; (b) misleading content used against a topic or person; (c) fake context when a genuine content is put into a fake context; (d) impostor

\footnotetext{
${ }^{3}$ The quotes translated from Portuguese to English are the author's responsibility. Here is the original version: " $\mathrm{E}$ não há argumentação racional que possa suplantá-la. Trata-se daquilo que os psicólogos cognitivos chamam de "viés da confirmação", ou seja, "quando alguém é confrontado por informações que contrariam sua visão de mundo, as chances de que aceitará o novo dado como um fato, mudará sua opinião, ou questionará o próprio sistema de crenças são um tanto baixas". Isto porque aceitar as informações que confirmam as nossas crenças fala mais alto do que "rejeitar aquelas que as contradizem"”' (SANTAELLA, 2018, p. 13).
} 


\section{Revista de Estudos Acadêmicos de Letras}

content when information that does not belong to personal and collective sources is associated with them; (e) manipulated content in which true information is manipulated to deceive the public; (f) fabricated content entirely fake built with the intention of misinforming and causing damage. ${ }^{4}$

Falsehood works and is spread, in any of its levels, because people are trapped in their own filter bubbles, sharing and having access to information that is in consonance with the beliefs.

Flores (2017) arguments that falsifier inferences are a powerful resource in the construction of fakes news, because they provide mechanisms that can simulate the feeling of truthfulness. In this context, Flores (2017) defines fake news as the manipulation of facts to serve certain interests. He argues that the acknowledgement of something as a fact is due to a process of interpretation that is guided by the communicator who, in this case, insinuates. Finally, he reinforces that even though we are responsible for our interpretations, the insinuator constructs the message in a way that manipulates the interpretations, to disorientate the reader of the text $t^{5}$.

Discourses are ideological (Foucault, 1971-2012) and so are fake news. The insinuators construct texts that follow the rules of what is considered true in a defined time and space which is makes them more believable. I defend here, therefore, that reflecting on fake news involves thinking about how we interpret them and what makes us get to conclusions. This process includes being aware of the author's strategies to guide our interpretations, but also of the discourses that construct our identities as social beings.

\section{Working with fake news}

In this topic, I discuss an experience in PIBID in which fake news were approached in the English language classroom. This experience was part of a didactic sequence that was developed in the $7^{\text {th }}$ grade class of a public school in Sergipe, between $20^{\text {th }}$ December 2017 and $17^{\text {th }}$ January 2018. The class plan was constructed based on some factors: the textbook's

\footnotetext{
4 “(a) sátira ou paródia que, embora não tenha intenção de causar mal, tem potencial para enganar; (b) conteúdo enganoso utilizado contra um assunto ou pessoa; (c) falso contexto quando um conteúdo genuíno é inserido em um contexto falso; (d) conteúdo impostor quando é colocado na boca de fontes pessoais ou coletivas informações que não são suas; (e) conteúdo manipulado em que uma informação verdadeira é manipulada para enganar o público; (f) conteúdo fabricado inteiramente falso construído com o intuito de desinformar e causar dano" (SANTAELLA, 2018, p. 30).

${ }^{5}$ In this paper, we use "text" referring not only to the written mode, but to all kinds of text (such as visual, oral etc.).
} 


\section{Revista de Estudos Acadêmicos de Letras}

content, that included computer parts and the use of such device; the grammatical topic, simple present; and a series of observations of the classroom where the plan would be developed. In this paper, I address only the second, third, and fourth classes due to the fact that they are the ones which regard fakes news.

On the second class of the plan the students and the teacher discussed some strategies to check the veracity of news. Then, in groups of five, students were asked to search for news using their cellphones or computers to bring to the following class. They should choose two pieces of news, one of them fake, one of them true, and explain why they thought of the chosen ones as fake or true, also the pieces of news should include the use of simple present, the grammatical topic that was present in all of the five classes. The idea of them working in groups came from the thought that some of them would not have access to internet; in groups, every student would be able to participate in the activity. In addition, by searching for news, they would have the opportunity to practice the ideas discussed on how to check the veracity of news and to bring to class content that was meaningful for them. Besides, it would be possible to understand why they thought of certain news as fake and others as truth and discuss these interpretations. In groups, especially if they used different devices to search for news, they would have the opportunity to observe what kinds of news each searcher would get, and start wondering why people had different results. As I have mentioned before, fake news is related to filter bubbles.

On the third class, the groups should bring the pieces of news they had chosen, so everybody could discuss why they were fake or true. However, none of the groups did the activity. When asked about the reasons why, some of them said they could not find news in English that included the use of simple present. Even though we discussed in the first topic of this paper that digital literacies go beyond the mechanical use digital devices, it is important that students know how to use these tools, so they can analyze the content in cyberspace. Therefore, we can see that talking to students about how to use computers or cellphones to make researches may be necessary like it was in this class. They should have been exposed to ways of researching on platforms like Google.

Since students did not take to class the pieces of news previously asked, on the following class, the teacher brought some to be discussed with students. They should be in the same groups of five people and analyze the pieces of news - which were written on the board with the author's name, publication date, and the website where it was published. Each group would decide whether they were truth or fake, explaining their decision. The discussions aimed 


\section{Revista de Estudos Acadêmicos de Letras}

at providing students with opportunities to see different points of views and reflect on their interpretations. When they were defending their points of view, they based their ideas on what they understood as believable. For instance, one of the pieces of news said that some celebrities were members of a secret cannibal restaurant ${ }^{6}$; all students agreed about the news being fake, because eating human meat did not feel so real, it was "a movie thing" (expression used by one of the students) ${ }^{7}$. This understanding of cannibalism was socially constructed and based on their experiences. In Brazil, and in most countries, it is not a common practice to eat human meat, this "truth" was not acknowledged by them, because it was not part of their understanding of reality. According to Jordão $(2007$, p. 21) "our truths are interpretations that we build from reality, and they will be more or less culturally legitimate if they are built from interpretative procedures more or less culturally accepted as revealers of truths." ${ }^{\prime 8}$ Hence, even though the insinuator used strategies to convince the reader that the news was true, the social experiences were stronger when defining what was "true".

Another piece of news discussed was about the discovery that "butterflies lived 50 million years earlier than thought"9. Students defined the truthfulness of this news based on the site in which it was published - it was the acknowledged newspaper website, The Guardian and on the author whose signature was visible and who mentioned in the article the sources of information and concrete evidence, like the group who made the scientific discovery, and when they found that out. Most of the students agreed that the news was true.

Finally, there was a piece of news that accused a clothing brand's collection of racism ${ }^{10}$. The class was divided regarding their opinion about the veracity of the news. Some of the students who interpreted the news as true justified their reading by saying that the author used images. In their opinions, images can show facts. However, as Ferraz (2014, p. 258) states "images, in their materiality, can be interpreted, and, at the same time generate interpretations, control people, alienate, educate." 11 In this sense, images are ideological and serve particular interests, which means that they do not indicate neutral truths. Some students even said that

\footnotetext{
${ }^{6}$ This piece of news was taken from a website that checks the veracity of news, analyzing it: https://www.snopes.com/fact-check/cannibal-restaurant/

${ }^{7}$ In the original version: "coisa de filme".

${ }^{8}$ Nossas verdades são interpretações que construímos da realidade, e terão maior ou menor legitimidade cultural se estiverem sendo construídas a partir de procedimentos interpretativos culturalmente mais ou menos aceitos como reveladores de verdades (Jordão, 2007, p. 21).

${ }^{9}$ Source: https://www.theguardian.com/science/2018/jan/10/fossil-evidence-reveals-butterflies-and-moths-lived50m-years-earlier-than-thought

${ }^{10}$ Source: https://www.snopes.com/fact-check/hm-release-equally-racist-collection/

${ }^{11}$ As imagens, em sua materialidade, podem ser interpretadas ao mesmo tempo em que podem gerar interpretações, controlar massas, alienar, educar”. (Ferraz, 2014, p. 258)
} 


\section{Revista de Estudos Acadêmicos de Letras}

sometimes pictures can be doctored, which was the case of the images used in the news under discussion. On the other hand, the students who believed that the news was fake observed that there was no mention of the author. The authorship of news was discussed on the second class, in the sense that an author who signs his or her post takes responsibility of what he or she is saying. One of the students made a comparison of news with gossip; according to him or her, when you tell something to another person without mentioning whom you got the information from, the person can be suspicious and incredulous. That is how we should behave concerning news: being always suspicious.

Regarding the procedures of the analysis, I have followed Freeman's (1998) proposal, based on four steps: naming, grouping, finding relationship, and displaying. Data for this research was gathered through field notes. First, they were labelled in the naming step which is mechanical and aims to avoid that the teacher-researcher claims to know what things mean right after reading them for the first time. The idea is to be "pushed to examine this sense of certainty, to expose it to scrutiny and questioning - not necessarily because you might be mistaken but to find out what is true and why." (FREEMAN, 1998, p. 99) There are three ways to code: from factors external to the data, creating them, or using participants' own words. The latter is the one I chose. After that, I grouped - second step - the codes. Just like when I was naming, the groups emerged from the data itself, by (re)assembling the codes, I have put those that shared similarities in the same groups. The emerging groups were unrealistic information, information that appears truthful, information that appears fake. In the first group, there is the example of cannibalism which is an unusual practice for students and it seems fictional, like what they see in movies. In the second one, students mentioned factors like author's name, concrete evidence, newspaper acknowledgment (if it is known for publishing facts), saying the source of information and the use of images. The last group includes the lack of the previously mentioned factors, that is, no mention of sources, of the author's name, of concrete evidence.

When finding relationship, I have discovered that the first group, unrealistic information, is connected to the second, information that appears truthful, because the unreal is what does not follow the rules of what can be considered true, that is, the social definitions of what is believable. The unreal, therefore, is what does not appear to be true. The first is related to the third one, information that appears fake, given that unreal information, for them, can be considered automatically fake. The factors mentioned in the third group are opposite to those mentioned in the second. Students created two opposite extremes that indicate what is fake and what is not, even though some of them questioned some factors like reading news that present 
the author's name. According to some of them, one can lie and sign their name, so this cannot be considered as sign for what telling the truth. The figure below illustrates the relations among the groups.

Figure 1: relationships among the groups

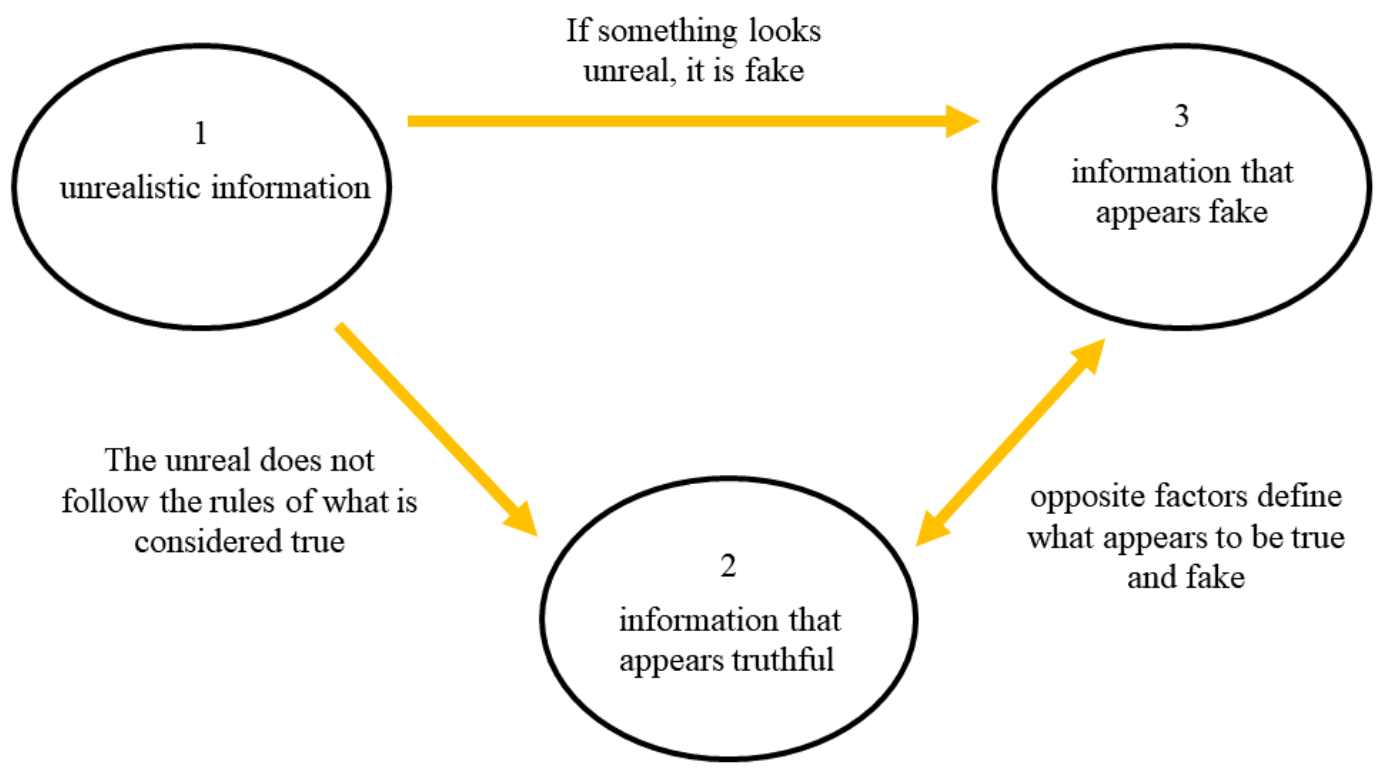

Source: author's elaboration

Note that although the unreal is considered fake automatically, the other way around does not happen, that is, fake does not mean unreal; something can appear to be true, but still be fake.

\section{Further considerations}

The concept of digital literacies takes into consideration the different sociocultural realities. The experiences we live in our social groups influence how we interpret and create content in the cyberspace. Therefore, being digitally literate goes beyond mastering technical skills, it requires reflection on the texts we can find in digital environments. However, from the experience in PIBID it is possible to conclude that sometimes it is necessary to discuss the mechanical skills needed to access content online and to find specific information.

Students seem to interpret some things as unrealistic, like people being cannibals. For them what seems unreal is fake information. Considering the relation between fake news and filter bubbles, students' association can be problematic, because it may indicate that they 
associate the unusual with falsehood. They also seemed sure that some factors indicate whether news is fake or not, namely the reputation of a website, identification of sources and concrete evidence. Hence, it was unclear for students that even famous websites can publish fakes news, due to power relations and different interests. Dealing with fake news involves being aware that discourses are ideological and permeated by power relationships, so both our interpretations and the text are ideological. Even though our readings of texts are important, it is also necessary to be aware that our interpretations can be manipulated to serve certain interests. Insinuators can make use of logical strategies in order to guide our interpretations, this can be done with images. In the experience analyzed, some students understood images as revealers of facts, but they are also ideological texts that can be manipulated and can only show one clipping of reality.

Teachers, therefore, have to acknowledge that working with technologies involves ideologies and interests; there is not a truthful way to use it in the classroom. Technology must be distrusted constantly and its use, negotiated (SELWYN, 2014). It is important to consider students' needs and encourage them with the practice of questioning, of thinking about where information and their own ideas come from.

In conclusion, for both teachers and students, the exercise of being suspicious towards news and texts in general is necessary. The suspicious should go beyond the veracity or fakeness of a piece of news; it involves being aware of the author's attempts to guide interpretations, and, especially, it requires reflections on how and why we read the way we do (MENEZES DE SOUZA, 2011).

\section{References}

BRAGA, D. B. Ambientes digitais: reflexões teóricas e práticas. São Paulo: Cortez, 2013.

FREEMAN, D. Doing Teacher Research: from inquiry to understanding. Boston:

Heinle Cencage Learning, 1998.

FERRAZ, D. M. Letramento visual: as imagens e as aulas de inglês. In: TAKAKI, N. H.; MACIEL, R. F. (Org.). Letramentos em terra de Paulo Freire. São Paulo: Pontes Editores, 2014. p. 255-270.

FLORES, P. J. Inferências falseadoras como base para a pós-verdade. Línguas e Letras, p. 20-32, 2017.

FOUCAULT, M. A ordem do discurso: aula inaugural no Collège de France, pronunciada em 2 de dezembro de 1970. Tradução de Laura Fraga de Almeida Sampaio. São Paulo: Edições Loyola, 2012. 


\section{Revista de Estudos Acadêmicos de Letras}

GILSTER, P. Digital literacy. New York: Wiley Computer Publications, 1997.

JORDÃO, C. M. As lentes do discurso: letramento e criticidade no mundo digital. Trab. Ling. Aplic., v. 46, p. 19-29, 2007.

KALANTZIS, M.; COPE, B. On Globalisation and Diversity. Computers and Composition, v. 23, p. 402-411, 2006.

LANKSHEAR, C.; KNOBEL, M. Digital Literacy and Digital Literacies. Nordic Journal of Digital Literacy, p. 8-20, 2006-2016.

MENEZES DE SOUZA, L. M. T. O Professor de Inglês e os Letramentos no século XXI: métodos ou ética? In: JORDÃO, C.M.; MARTINEZ, J.Z; HALU, R.C. (Org.). Formação (Des) formatada: práticas com professores de língua inglesa. São Paulo: Pontes, 2011. p. 279-303.

NASCIMENTO, A. K. O. O ensino de língua inglesa sob o viés dos letramentos digitais. In: ZACCHI, V. J.; STELLA, P. R. Novos letramentos, formação de professores e o ensino de língua inglesa. Alagoas: Edufal, 2014. p. 53-73.

PENNYCOOK, G. et al. Prior exposure increases perceived accuracy of fake news. Journal of Experimental Psychology General, p. 1865-1880, 2018.

SANTAELLA, L. A pós-verdade é verdadeira ou falsa? 1. ed. São Paulo: Estação das Letras e Cores, 2018.

SANTAELLA, L. Comunicação ubíqua: repercussões na cultura e na educação. São Paulo: Paulus, 2013.

SANTAELLA, L. Temas e dilemas do pós-digital: a voz da política. São Paulo: Paulus, 2016.

SELWYN, N. Distrusting Educational Technology: critical questions for changing times. New York: Routledge, 2014. 